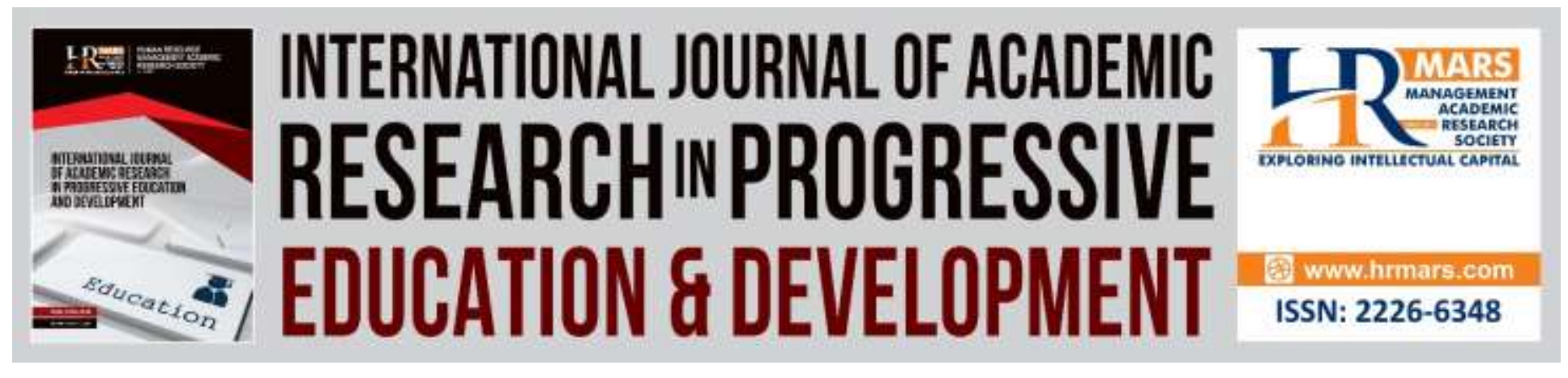

\title{
The Effect of Edutainment on Higher Order Thinking Skills among Year Five Students
}

\author{
Hamidah Mat, Nik Azmah Nik Yusoff
}

To Link this Article: http://dx.doi.org/10.6007/IJARPED/v8-i4/6435

DOI: 10.6007/IJARPED/v8-i4/6435

Received: 04 July 2019, Revised: 19 August 2019, Accepted: 28 August 2019

Published Online: 06 September, 2019

In-Text Citation: (Mat \& Yusoff, 2019)

To Cite this Article: Mat, H., \& Yusoff, N. A. N. (2019). The Effect of Edutainment on Higher Order Thinking Skills among Year Five Students. International Journal of Academic Research in Progressive Education and Development, 8(4), 55-65.

\section{Copyright: (C) 2019 The Author(s)}

Published by Human Resource Management Academic Research Society (www.hrmars.com)

This article is published under the Creative Commons Attribution (CC BY 4.0) license. Anyone may reproduce, distribute, translate and create derivative works of this article (for both commercial and non-commercial purposes), subject to full attribution to the original publication and authors. The full terms of this license may be seen

at: http://creativecommons.org/licences/by/4.0/legalcode

Vol. 8(4) 2019, Pg. 55- 65

http://hrmars.com/index.php/pages/detail/IJARPED

JOURNAL HOMEPAGE

Full Terms \& Conditions of access and use can be found at http://hrmars.com/index.php/pages/detail/publication-ethics 


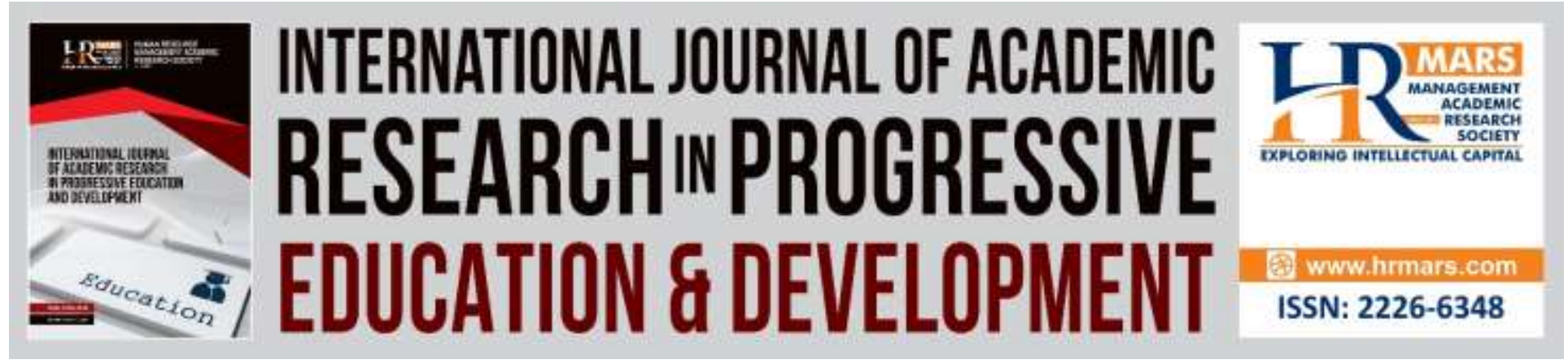

\title{
The Effect of Edutainment on Higher Order Thinking Skills among Year Five Students
}

\author{
Hamidah Mat, Nik Azmah Nik Yusoff \\ Universiti Pendidikan Sultan Idris \\ Email: hamidah22605@gmail.com
}

\begin{abstract}
The purpose of this study is to determine the effect of edutainment on the Higher Order Thinking Skills in Year Five students. This study utilises quasi-experimental design using pre and post-tests. The development of edutainment module is based on the ADDIE model. The samples comprised of 33 treatment group students and 33 control group students who were randomly selected. The instruments used are pre-test and post-test. Based on the findings of the independent sample ttest for higher order thinking skills applying, analyzing, evaluating and synthesizing, showed significant differences [ $\mathrm{t}(64), \mathrm{p}<.05$ ) between the post-test scores of treatment and control groups i.e. all levels showing $p=0.00$. In conclusion, this study has found that learning by entertaining students was effective in raising the students' level of thinking skills. The implication of the study showed that edutainment learning can be used by primary school science teachers to improve higher order thinking skill in students.
\end{abstract}

Keywords: Edutainment, ADDIE model, Higher Order Thinking Skills

\section{Introduction}

In shaping an intellectual, competitive and skillful generation of the future, the mastery of science subject is very important. Hence, science teaching should be seen as not only to pass examinations alone, but also for the appreciation and practice of what is learned. Teachers should be smart and creative in selecting and designing appropriate teaching and learning methods as well as attracting students to follow.

Therefore, the chosen teaching method should take into account the inclination and ability of students based on age and thinking ability. A good teaching method will help students to follow their lesson as well as to acquire knowledge, skills and inculcate deep interest in the students. Teaching methods need to be diversified and adapted according to the topic and theme selected so as to attract the attention of students and to have the maximum impact on the teaching and learning they received (Jamir, Halim, \& A'dawiyah, 2012; Khalid, Pahi, \& Ahmed, (2016). 
INTERNATIONAL JOURNAL OF ACADEMIC RESEARCH IN PROGRESSIVE EDUCATION AND DEVELOPMENT

Vol. 8, No. 4, 2019, E-ISSN: 2226-6348 @ 2019 HRMARS

\section{Problem Statement}

Ineffective teaching and learning activities of science subjects at primary school level can affect students' interest and understanding when they pursue secondary school. The phenomenon of memorizing facts, for example, has been detected for a long time in students (Grove \& Lowery, 2012; Madrid, Ahmed, \& Kumar, 2019). This situation causes many students to only grasp the basic concepts of science but fail to manipulate objects for problem solving even though these concepts have been studied.

\section{Research Objective}

The purpose of the study was to examine the effects of edutainment learning using higher order thinking questions in Year Five pupils.

\section{Research Question}

This study focuses on the following questions:

1. Is the edutainment learning module effective on the students' higher order thinking skills through the ability to answer the following questions:
(a) Apply
(b) Analyze
(c) Assess
(d) Synthesis

\section{Literature Overview}

\section{Cognitive Learning Theory}

Bruner (1960) argues that naturally one learns by discovering the relationship between the various stimuli found in the environment. This statement is supported by Piaget (1971) that students organize various changes into their schemes during learning through the process of adaptation to the environment. He also pointed out that learning is a specific process determined and stimulated by the environment either inside or outside of the classroom. The development is described as a general process that occurs spontaneously as a result of physical and social interactions and various mental functions.

Vygotsky (1978) explains that student cognitive development is a fundamental transformation which is biologically setting up to the highest psychology. He suggested the concept of the development zone near the zone of proximal development (ZPD) i.e. the space between the student's existing knowledge or skills and his potential level.

Hence, the actual learning involves the acquisition of knowledge. These views usually will implicate on how to teach and communicate information to students as well as evaluating and testing how many students are able to remember what they have learned (Mayer, 2002). According to Mayer, meaningful learning occurs when students build the knowledge and cognitive processes needed to solve a problem. Problem solving involves individuals forming a way to achieve goals that have never been achieved before and seeking ways to achieve them. 


\section{ADDIE Model}

The ADDIE model stands for Analysis, Design, Development or Production, Implementation or Delivery and Evaluations. The ADDIE model was developed by Dick and Carry (1996) to help design a learning system. Here is an example of activities at each stage of the development of a model or learning method, namely:

\section{Analyze}

At this point, the main activity is to analyze the need for a new model development or learning method and studying the qualifications and conditions of the development of a new model or learning method. Development of new learning methods begins when problems arise in the present model or learning methods. Problems occur because the existing model or learning method is irrelevant to the target needs, learning environment, technology, student characteristics, and so on. After analyzing the need for a new model development or new learning methods, researchers also need to analyze the feasibility and conditions of this development. Analyzing process is done by answering the following questions:

(1) What new model or method can overcome the present problem of learning?

(2) What new model or method has the support of the facility to be applied?

(3) Whether the teacher is able to apply the new learning model or method?

In this phase, problems like is the design of a model or method excellent or restrictions such as unavailable tools and money constraints for teachers to afford can be avoided. An analysis of new learning methods needs to be done to determine if the learning method can be applied.

\section{Design}

Designing a model or learning method has similarities with designing teaching and learning activities. This activity is a systematic process that begins with setting goals, designing scenarios or learning activities, planning learning levels and providing teaching aids. This model design or learning method is still conceptual and will be the basis of the next development process.

\section{Development}

Development in the ADDIE model is the realization of the product design. In this phase, the conceptual framework of the application of a new model or method of learning is organized. In the development stage, the conceptual framework is turned into a product that is ready to be implemented. For example, in the design stage, the use of a new model or method is still conceptually designed. Then, in the development phase, learning device with the new model or method will be created or completed, for example in lesson plans and the provision of teaching aids. 
Vol. 8, No. 4, 2019, E-ISSN: 2226-6348 @ 2019 HRMARS

\section{Implementation}

In this phase, plans and methods that have been developed will be implemented in real life situations i.e. in the classroom. During this process, the design of the model or method developed will be applied to the actual situation. The learning process is delivered according to the new model or method developed. After applying the methodology, preliminary assessment to provide feedbacks on the implementation of the next model or method will be carried out.

\section{Evaluation}

Evaluation is done in two forms i.e. formative and summative evaluation. Formative assessment is performed at the end of each learning session (weekly) while summative evaluation is done after the whole event ends (13 weeks). Summative assessment measures the final competence of the subject or learning objective to be achieved. Evaluation results are used to provide feedbacks to researchers. If the new model or method has not achieved the competence required, revisions are made in accordance to the results of the assessment or requirements.

\section{Research Methodology \\ Respondents}

The population of the study consisted of a total of 210 Year Five students of a primary school in Negeri Sembilan. To get maximum results, a study should cover the entire individual involved. However, this study could not meet that criteria. Therefore, the researcher has selected 66 samples which can represent the samples studied. These students have already sat their Lower School Self-Assessment (PKSR) for the final semester of the 2015 session. Their test results will be analyzed to select 66 samples based on their achievement. The types of questions assessed in the examination are based on the Primary School Achievement Test (UPSR) format issued by the Ministry of Education Malaysia. To carry out this study, the researcher has divided the selected sample into two groups, namely 33 students for the treatment group and 33 students for the control group.

\section{Instrument}

Pre and Post-Test

Pre-test containing six subjective tests were given to students before the teaching and learning process is carried out. This is to evaluate the existing knowledge of the students in the items of higher order thinking skills. The questionaire provided by the researcher was reviewed by some field experts to ensure the validity of the content and the relevance of the questions. This technique has been used by (Zakiah et al., 2013) to validate in terms of content. Researcher then reviewed and recorded the pre-test results.

Post-test was conducted at the end of the thirteenth week and researcher also reviewed and recorded the post-test results. The pre and post-test questions built by researcher are equivalent and based on the Test Specification Table (JSU) where the questions were different but of equivalent standard. Pre and post-test questions are based on the 6 levels of Bloom's Taxonomy. 
Vol. 8, No. 4, 2019, E-ISSN: 2226-6348 @ 2019 HRMARS

\section{Data Collection}

This study was conducted at a primary school in Senawang, Negeri Sembilan district. Before proceeding with the intentions and data collection, research proposals were submitted and approved by the Education Planing and Research Department (EPRD), Ministry of Education Malaysia.

Division of the treatment and control groups were performed by the school administrators based on the mid-year examination results for science subject according to the grades shown in Table 1.0 .

Table1.0:

Score Range

\section{Grade}

A

B

C

D

$E$

TH

\section{Score}

$80-100$

$65-79$

$50-64$

$40-49$

0-39

$\mathrm{TH}$

Source: Grade Achievement of the School Examination Analysis System (SAPS), Ministry of Education Malaysia

In this study, researchers conducted 13 teaching and learning sessions for each treatment and control group. Both groups were taught the same topics that are related to the Year 5 science syllabus but using different methods. The control group was taught using traditional methods while the treatment group was taught using a fun learning method. Pre-test and post-test were used to evaluate students' understanding of the subject.

\section{Data Analysis}

The data obtained in this study have been analyzed using the t-test sample inferential statistics. In this study, the null hypothesis has been tested at a significant level of 0.05 . According to Chua (2012), paired sample t-test is used when each individual in the sample is measured twice and both normalized scatter measurement data are used to compare. This means that each individual from the experimental group and the control group has two scores for two different levels in the free variables (pre and post). 
Vol. 8, No. 4, 2019, E-ISSN: 2226-6348 @ 2019 HRMARS

According to Wiersma (1991), the results of the study will only be rendered after analysis. Field notes that have been collected will be compiled and synthesized. Data that is then summarized will be manipulated, and basically reduced so that it will provide the information needed for the explanation and test hypothesis. Quasi-experimental study analysis is not as easy as analysis in the experimental studies. Advanced statistical procedures should be used to account for random deficiencies in comparison groups (Kato, 2013). The determination of an appropriate unit of analysis relates directly to the research hypotheses and questions, samples, and sample assignments for the study conditions (Cohen J., 1988). Researchers need to be clear in linking the selected analysis unit for major statistical analysis. For the purpose of this study, researcher uses both types of statistics, descriptive and inferences. Analysis was conducted using the Statistical Program for Social Science (SPSS) version 20.0. To facilitate data analysis, researcher has set up the following frameworks: -

Table 1.2

Data Analysis Framework

\begin{tabular}{clllc}
\hline Number & \multicolumn{1}{c}{ Objective } & Method used & Data source & $\begin{array}{c}\text { Data analysis } \\
\text { techniques }\end{array}$ \\
\hline 1 & $\begin{array}{l}\text { Examine the } \\
\text { effectiveness of } \\
\text { edutainment learning } \\
\text { on student's higher } \\
\text { order thinking skills. }\end{array}$ & Pre and post test & $\begin{array}{l}\text { Pre and post } \\
\text { test scores }\end{array}$ & t-test \\
& & & \\
& & &
\end{tabular}

\section{Discussion}

Achievement Testing of Higher Order Thinking Skills Questions through Post Test for Treatment Groups and Control Groups

The effect of using edutainment based learning can be seen through high subtotal thinking skills analysis using pre and post-test. Based on the findings of the independent sample t-test for the application of higher order thinking skills (Tables 1.3 and 1.4), there was a significant difference between the treatment group's post-test scores ( $\min =5.76, \mathrm{SD}=2.990)$ and the control group's post-test scores $(\min =8.73, \mathrm{SD}=3.511) ; \mathrm{t}(64)=-3.699,(p<.05)$. This means that null hypothesis $\mathrm{H}_{2}$ a that there is no significant difference to the higher order thinking skill is applied.

Based on the results of the independent t-test samples for higher order thinking skills (Table 1.3 and 1.4), there was a significant difference between the treatment group's post-test scores ( $\min =17.82, \mathrm{SD}=5.059)$ and control group's post-test scores ( $\min =2.10, \mathrm{SD}=3.005)$; $\mathrm{t}$ $(64)=15.148,(p<.05)$. This means that null hypothesis $\mathrm{H}_{b} 2_{b}$ that there is no significant difference to the higher order thinking skill of the analyzing is denied. 
Vol. 8, No. 4, 2019, E-ISSN: 2226-6348 @ 2019 HRMARS

In addition, the results of the independent t-test samples for higher order thinking skills assessed (Table 1.3 and 1.4), there was a significant difference in the post-test scores of control and treatment groups $(\mathrm{min}=4.58, \mathrm{SD}=1.582) \mathrm{min}=2.30, \mathrm{SD}=2.038) ; \mathrm{t}(64)=5.060,(\mathrm{p}<.05)$. This means that null hypothesis $\mathrm{H}_{c} 2_{c}$ that there is no significant difference to higher order thinking skills is rejected.

In addition, the results of the independent t-test sample for higher order thinking skills synthesized (Table 1.3 and 1.4), there was a significant difference between post-test treatment group's score ( $\min =5.67, \mathrm{SD}=.692)$ and control group's score $(\min =3.88, \mathrm{SD}=1.6353) ; \mathrm{t}(64)=$ $5.785,(p<.05)$. This means that null hypothesis is not significance there is no significant difference to synthesized higher order thinking skills.

Table 1.3

Statistical Data on Higher Order Thinking Skills Subtances through Post-Test

\begin{tabular}{ccccc}
\hline Score & $\begin{array}{c}\text { Mean of } \\
\text { Treatment } \\
\text { group }\end{array}$ & $\begin{array}{c}\text { Mean of control } \\
\text { group }\end{array}$ & $\begin{array}{c}\text { Standard } \\
\text { deviation of } \\
\text { treatment group }\end{array}$ & $\begin{array}{c}\text { Standard } \\
\text { deviation of } \\
\text { control group }\end{array}$ \\
\hline Application & 5.76 & 8.73 & 2.990 & 3.511 \\
Analysis & 17.82 & 2.10 & 5.059 & 3.005 \\
Evaluation & 4.58 & 2.30 & 1.582 & 2.038 \\
Synthesize & 5.67 & 3.88 & .692 & 1.6353 \\
\hline
\end{tabular}

Table 1.4

Independent t-test Against Sub-Proficiency Higher Order Thinking Skills through Post-Test

\begin{tabular}{ccccccc}
\hline & $F$ & Sig & T & Df & $\begin{array}{c}\text { Sig Two } \\
\text { Tails }\end{array}$ & $\begin{array}{c}\text { Mean } \\
\text { difference }\end{array}$ \\
\hline Application & .857 & .358 & -3.699 & 62.414 & .000 & -2.970 \\
Analysis & 9.607 & .003 & 15.148 & 64 & .000 & 15.515 \\
Evaluation & 4.920 & 0.30 & 5.060 & 64 & .000 & 2.273 \\
Synthesize & 6.498 & .013 & 5.785 & 64 & .000 & 1.788 \\
\hline
\end{tabular}

\section{Discussions and Conclusions}

The results of the analysis have shown that there was a significant discrepancy between the treatment group and the control group. The increase in students' achievement in the treatment group showed that teaching and learning based on the comfort of students is appropriate.

Students from both groups of studies have been given pre and post-test questions comprising of equivalent questions i.e. different questions but of equivalent level. The findings have shown that both groups succeeded in improving their achievement, but what was more interesting is the higher achievement in the treatment group students. Obvious here, edutainment based learning in students has had a positive impact on student's achievement as compared to traditional methods of learning. This is because the activities contained in the module are fun for the students. They can play while learning and actively participate in group 
Vol. 8, No. 4, 2019, E-ISSN: 2226-6348 @ 2019 HRMARS

activities. The results of this study have succeeded in supporting the statements of Bodrova and Leong (2001, 2003), Bruce (2001), Owocki (1991), and Sawyers and Rogers (1998) which previously explained that students' cognitive development can be expanded through fun learning.

The findings of this study reinforced with the combination of Cognitive Theory and Amabile Intrinsic Motivation Theory have shown that learning technique based on the edutainment learning has the potential to reduce the cognitive burden of students which has been an issue with the decline in the number of students achieving excellence in science subjects especially at UPSR level.

The findings of this study also added to an understanding of the concept of involvement when the combination of Cognitive Theory and Amabile Intrinsic Motivation Theory can be proven to affect the long-term memory in the students. This means that each student is bound to perform every activity that affects long-term memory which can further enhance their knowledge. The empirical findings of this study can be used as an indicator of the need for this module-based learning technique to be developed into one of the teaching aids for teachers and students during the teaching and learning process.

The findings have also shown the potential of edutainment learning which can be linked to ideas that can be used to help each student develop knowledge, skills and learning features for life and work. By using Syoknya Belajar Sains module, four elements can be generated in the students into making them to be successful students, confident individuals, responsible citizens as well as contributing to the well-being of the nation.

Successful students are students who are able to practice literacy, communication and numeracy skills; think creatively, critically and freely; study freely or collectively; make good assessments and able to apply various types of learning in new situations.

Individuals who are confident can also connect with others and manage themselves; develop and convey their own ideas and opinions; assessing risks and making informed decisions; and achieve success in many different areas of activity.

Responsible individuals can develop knowledge and understanding of the world and of Malaysia; understanding of different ideas; of choice feedback and results; of information development; and of ethical views on current issues.

This study is generally an experimental study on the use of a edutainment based learning approach. Based on the findings of the study, this approach is particularly suitable for constructivist teachers who have had much experience constructing a constructive classroom.

Thus the findings of this study contributed to a meaningful knowledge and information to address the problems inherent in the education system in primary school science subject in 
Malaysia today. The results of this study can also be used as a source of information to improve the effectiveness of the education curriculum and teaching and learning process of primary school science teachers. Related parties may use the information obtained to improve the country's education system to produce quality students with first-class thinking as envisioned within the 10-year Plan of Malaysia and achieve developed nation status in line with Vision 2020. Additionally, some suggestions have been submitted for future studies to complement the data obtained and to contribute to human development, especially in terms of quality, balance and the first ones involved in science education in Malaysia.

The development of a balanced and successful student must begin with a quality and effective education system. The ability to attain Philosophy of National Education (1996) relies on the capability of teachers to implement and provide an excellent, knowledgeable, skillful, educated and motivational education process. Teachers are the key to the success of learning process based on comfort in order to improve self higher order thinking skills in students. When exersizing higher order thinking skills in teaching, teachers must own knowledge and skills to diversify teaching methods and approaches in order to effectively implement and applying these skills to their students. Therefore, teachers need to have enough trainings and knowledge to enable them to exersize effective teaching. Students should be given guidance on higher order thinking skills that can be appreciated, held and practiced throughout their lives, especially in decision-making. Additionally, students have the advantage and opportunity to enhance their interpersonal and intrapersonal communication skills, as well as how they can effectively communicate their own opinions and considerations. This is an important feature when competing in a challenging life of the modern world.

\section{Acknowledgement}

In the name of Allah, the Most Gracious, the Most Merciful. All the praises and thanks be to Allah; and may peace be upon the Great Messenger Prophet Muhammad S.W.T, the Prophet of light and his companions. Alhamdullilah, with your guidance I am able to complete this study. My endless gratitude and thank you to my supervisor, Professor Dr. Nik Azmah binti Nik Yusoff, who is always there to give me encouragement and guidance until the completion of this research. I will always be indebted. To my beloved husband, Marzuki and my beloved children, Arjuna Akhmal, Andika Fahmi, Aniq Rayyan and Ain Nurqalisya, my infinite gratitude to them, for always being understanding, for always being patient, for always praying for my success to complete this research and for their sacrifices. I can't thank you enough.

\section{Corresponding Author}

Hamidah binti Mat

Faculty of Education and Human Development

Universiti Pendidikan Sultan Idris

35900 Tanjong Malim

Perak, Malaysia

Email : hamidah22605@gmail.com 
INTERNATIONAL JOURNAL OF ACADEMIC RESEARCH IN PROGRESSIVE EDUCATION AND DEVELOPMENT

Vol. 8, No. 4, 2019, E-ISSN: 2226-6348 @ 2019 HRMARS

\section{References}

Bodrova, E., \& Leong, D. J. (2003). Chopsticks and Counting Chips: Do Play and

Bruce, T. (2001). Learning Through Play: Babies, Toddlers and the Foundation Years. London: Hodder \& Stoughton

Bruner, J. S. (1960). In The Process of Education (pp. 12-13). http://doi.org/10.1017/CBO9781107415324.004

Chua, Y. P. (2012). Kaedah dan Statistik Penyelidikan Buku 2: Asas Statistik Penyelidikan

Cohen, J. (1988). Statistical Power Analysis for the Behavioral Sciences. http://doi.org/10.1234/12345678

Developmental Research: Emergent Trends in Educational Research. Kuala Lumpur: Pearson Malaysia.

Dick, W. (1996). The Dick and Carey Model: Will it survive the decade? Educational Technology Research and Development, 44(3), 55-63. http://doi.org/10.1007/BF02300425

Foundational Skills Need to Compete for the Teacher's Attention in an Early Childhood Classroom? Young Children, 58, 10-17.

Grove, N. P., \& Lowery Bretz, S. (2012). A continuum of learning: from rote memorization to meaningful learning in organic chemistry. Chemistry Education Research and Practice, 13(3), 201. http://doi.org/10.1039/c1rp90069b http://www.coursesmart.com/9780137144556

Jamir, A. M. S., Halim, A. T., \& A'dawiyah, I. (2012). Pembelajaran Aktif dalam Pengajaran dan Pembelajaran Berkesan Pendidikan Islam. Jurnal IPG Kampus Pendidikan Islam, 1-22.

Kato, K. (2013). Quasi-Bayesian analysis of nonparametric instrumental variables models. The Annals of Statistics, 41(5), 2359-2390. http://doi.org/10.1214/13-AOS1150

Khalid, N., Pahi, M. H., \& Ahmed, U. (2016). Loosing your best talent: Can leadership retain employees? The dilemma of the banking sector of Hyderabad Sindh, Pakistan: A mediation investigation. International Review of Management and Marketing, 6(3), 608616.

Madrid, D., Ahmed, U., \& Kumar, R. (2019). Examining the Impact of Classroom Environment on Entrepreneurship Education: Case of a Private University in Bahrain. Journal of Entrepreneurship Education, 22(1), 1-8.

Mayer, R. E. (2002). Rote Versus Meaningful Learning. Theory Into Practice, 41(4), 226-232. http://doi.org/10.1207/s15430421tip4104_4

Owocki, G. (1999). Literacy through play. Portsmouth, NH:Heinemann.

Piaget, J. (1971). Psychology and epistemology. Orion Press book.

Practical Guide for Parents, Caregivers and Teachers. Washington, DC: National Association for the Education of Young Children.

Sawyers, J. K. \& Rogers, C. S. (1988). Helping Children Develop through Play: A

Siraj, S., Alias, N., DeWitt, D., \& Hussin, Z. (2013). Design and

Vygotsky, L. S. (1978). Interaction between Learning and Development. Mind and Society. http://doi.org/10.1016/S0006-3495(96)79572-3

Wiersma, W. (1991). Introduction to Research Methods in Education. British Journal of Educational Technology (Vol. 40). Retrieved from 